\title{
Apartman Temizleyicisinin Bir Kadın Olarak Portresi: Kul
}

\author{
Portrait of an Apartment Cleaner as a Woman: The Slave
}

\section{EFNAN DERVIŞSOĞLU*}

* Asst.Prof., Kocaeli University, Kandıra Vocational School, Akdurak Mah., Mehmet Taner Cad. No:40, 41600 Kandıra/Kocaeli, Turkey, E-mail: efnan.dervisoglu@kocaeli.edu.tr (D) https://orcid.org/0000-0003-0763-9141

Öz: Önce öykü yazarı kimliğiyle tanınan Seray Şahiner, 2014’te yayımlanan ilk romanı Antabus'un ardindan "Reklamı Atla" adıyla denemelerini bir araya getirir. Yazarı ikinci romanı Kul ise 2017'de yayımlanır. Apartman merdivenlerini temizlemekle geçimini sağlayan Mercan'in yaşamina odaklanan Kul, 2018'de Şahiner'e Orhan Kemal Roman Armağani'nı kazandırır. Kul, yalnızlığı ve çaresizliği ile baş etmeye çalışırken umutlarına tutunan Mercan'in yaşamındaki eksiklikleri, televizyonla kurduğu ilişkiyi, çekip gitmiş kocasıyla doğmamış çocuğuna duyduğu özlemi ve bu arada aradiğı çareleri anlatan bir romandır. Mercan, emeğiyle geçinen ve fark edilmeden yaşamın sürdüren kadınların temsilcisi konumundadır. Bu makale; "Yukarıdakiler ve aşağıdakiler", "Mercan'ın yalnızlığı ve televizyonla kucaklaşma", "Sokağa çıkan Mercan'ın bireyselliğine yürüyüşü” ile "47. Orhan Kemal Roman Armağani" alt başliklı bölümlerden oluşmakta ve Mercan'in kendi ayakları üzerinde durma çabasının kendine özgü niteliklerini ortaya koymayı amaçlamaktadır.

Anahtar kelimeler: Seray Şahiner, Edebiyat, Roman, Kul, Kadın

Abstract: Seray Şahiner, first known as a story writer, she gathered her essays under the title "Skip the Ad", after her first novel Antabus was published in 2014. The author's second novel The Slave was published in 2017. "Kul" focusing on the life of Mercan who makes her living by cleaning apartment stairs bring Şahiner in 2018 the Orhan Kemal Novel Gift. "Kul" is a novel about Mercan's deficiencies in her life, her relationship with television, her longing for her deceased husband and unborn child, and the remedies she seeks in the meantime while she tries to cope with her loneliness and despair. Mercan represents the women who make a living through their labor and lead their lives unnoticed. This article consists of sections with subtitles "Those uppers and those below", "Mercan's solitude and embrace with television", "Mercan's walk out into the street to her individuality" and "47. Orhan Kemal Novel Gift" and aims to reveal the unique qualities of Mercan's effort to stand on her own feet.

Keywords: Seray Şahiner, Literature, Novel, The Slave, Woman

\section{Giriş̧}

2006’da Yaşar Nabi Nayır Gençlik Ödülleri’nde “Dikkate Değer” bulunan Gelin Başı, Seray Şahiner'in ilk kitabı olarak 2007'de yayımlanır. Yazarın ikinci kitabı Hanımların Dikkatine de öykülerden oluşur ve 2011'de okuyucuyla buluşur; aynı yıl, Marmara Üniversitesi'nde Sinema yüksek lisansını tamamlayan Şahiner, bu kitabıyla 2012'de Yunus Nadi Öykü Ödülü’nü kazanır. Kul'un Mercan’ı gibi işçi 
olan Leyla'nın yaşamına odaklanan Antabus romanı 2014'te yayımlanır. Tatbikat Sahnesi'nce sahnelenen Antabus, 2016'daki Afife Tiyatro Ödülleri'nde Nihal Yalçın'a Yılın En Başarılı Kadın Oyuncusu Ödülü'nü kazandırırken Şahiner, Cevat Fehmi Başkut Özel Ödülü’nün sahibi olur. 2016'da “Reklamı Atla” adıyla denemelerini bir araya getiren yazarın bu çalışmaya konu olan romanı Kul, 2017 tarihlidir. 2018'de Orhan Kemal Roman Armağanı'nı kazanan Kul, Toy Sahnesi'nce sahnelenirken Mercan karakterine Dolunay Soysert hayat verir. Yazarın on iki öyküsünü içeren Hepyek 2019'da yayımlanır; 2021'e gelindiğinde okuyucu Şahiner'in yeni bir romanıyla buluşur: Ülker Abla.

Şahiner gerek öykü kitaplarında gerekse de ilk romanı Antabus'ta kadınların dünyasına eğilir. Ezilen, şiddet gören, Eray Ak'ın deyişiyle "bir şekilde toplumun görünmez halkası hâline gelmiş kadınların dünyasına kırılgan olmaya mahkûm pencereler" açar. ${ }^{1}$ Yazar, sesini çıkaramayanları, konuşsa da dikkate alınmayanları yazmanın; var olan sorunların farkına varmayı beraberinde getireceği, bu noktada edebiyatın konuşma-tartışma fırsatı vereceğini düşünür. Edebiyatın böyle bir zorunluluğu bulunmamakla birlikte Şahiner, yazar sorumluluğuyla bu bakış açısını sürdürür ve kendisiyle yapılan bir söyleşide şunları söyler:

Baskı gören kadınları yazmam, özgür kadın yok genellemesi içermiyor tabii ki. Ama şu da var, ben zaten derdimi uluorta anlatabiliyorum. O noktada bu imkânı paylaşma sorumluluğu doğuyor. Kimin tarafındaysam onun hikâyesini anlatmaya çalışıyorum aslında. Dertleri anlatmayı sadece haberlere birakacak lüksümüz yok. Bugünün üçüncü sayfa haberi yarın arşiv olacak. Edebiyat derdi daha uzun soluklu tartışma, çözüm bulmak için üzerine bir arada konuşma imkânı veriyor. ${ }^{2}$

$\mathrm{Bu}$ çalışmaya konu olan Kul, Mercan karakteri üzerinden ilerleyen bir roman. Seray Şahiner, Mercan'ın; evinde, sokakta, elinde temizlik beziyle silip temizlediği apartman merdivenlerinde düşündügü, hissettiği ne varsa önümüze seren bir roman kurgular. Yoksulluğunda ve çaresizliğinde debelenip dururken Edip Cansever' in "Umudu dürt / Umutsuzluğu yatıştır"3 dizelerini özümsemiş gibi davranan Mercan'ın hikâyesini anlatır. Tek geçim kaynağı apartman temizleyiciliğiyle hem evi çekip çevirmiş hem de işsiz ve esrarkeş kocasına bakmış olan Mercan'ın iki dileği vardır: İlki kocasının eve dönmesi, ikincisi ise bir çocuğa sahip olabilmektir. Kocasının gidişiyle bu ikinci dileğinin gerçekleşmeyecek oluşuna üzülen Mercan'ın roman boyunca tanık olduğumuz bekleyişi, "evli ve çocuklu” bir yaşamı arzulamass nedeniyledir. Şahiner iç konuşma tekniğine başvurduğundan yalnızca yaşadıklarını değil hissettiklerini de biliriz Mercan'ın. Aklından geçenleri, yoksulluğunu, yalnızlığını, çaresizliğini ve bütün bunlara dayanabilmek için umutlarına sarılmaktan vazgeçmeyişini... Şahiner, Mercan'ın iç dünyasında girmediğimiz bir yer bırakmaz. İstanbul gibi bir metropolde, kısıtlı imkânlarla tek başına ayakta kalma mücadelesi veren Mercan'ın hikâyesini anlatırken bir bakıma onun ve onun gibilerin görünmezliğini de ortadan kaldırır.

\footnotetext{
${ }^{1}$ Eray Ak, "Sadaka Niyetine Mutluluk", Cumhuriyet Kitap Eki, 1412 (2017), s.8.

${ }^{2}$ Beyza Selen Çavuş, “Seray Şahiner'le Söyleşi”, Varlık, 1318 (2017), s.94.

${ }^{3}$ Edip Cansever, Sonrası Kalır I, İstanbul: Yapı Kredi Yayınları, 10. bs., 2013, s.619.
} 


\section{Yukarıdakiler ve Aşağıdakiler}

Şahiner, Kul'un hemen başında Mercan'ın niçin kendisine "Mercan Hanım” denmesinden hoşlanmadığını, nedenleriyle okuyucuya iletir. Bu ileti, Mercan'ın; temsil ettiği sosyal grupla, üst orta ve üst gelir grubu arasında gözlediği kutuplaşmanın bilincinde oluşunun ipuçlarını verir:

Bilir çünkü, bu hanımlık, onu bir basamak yukarı taşımaz. Daha ziyade, merdivenden aşağı seslenilirken kullanılan bir 'Mercan Hanıım'lıktır onunkisi. Bir mesafe koymak, senlibenli olmamak, sıcak çaydanlığın sapını bezin ucuyla tutuvermek gibi bir şeydir onun yüzüne Mercan Hanım denmesi. Arkasından konuşulurken, yine bildiğimiz Mercan'dır o. ${ }^{4}$

Yaptığı işi sevmese de para kazandırdığı, geçimini sağladığı için memnundur Mercan. Bu işin, yaşam düzeyini yükseltmeyeceğini, onu televizyonda gördüklerine ulaştıramayacağını bilir; temizliğe gittiği apartmanlarda oturan kadınlarca küçük görüldügünü, arkasından konuşulduğunu, en kötüsü de görmezden gelindiğini bilerek aynı apartmanlarda çalışmayı sürdürür, buna mecburdur. İşini ciddiyetle yaptığı günlerde bile kullanacağı suyu kapı önlerine koymayarak, deterjandan kısarak, kendisiyle insanca bir iletişim kurmayarak ona ait olduğu sınıfı hatırlatıp duran bu kadınlardan bir eksiğinin olmadığını düşünen Mercan için magazin programlarında gördükleri kadar lüks içinde olmasalar da bu kadınlar da kendisinin üstündedirler. İş kıyafetlerini çıkarıp özenle Samatya Meydanı'na gittiği gün, o hazzetmediği "hanımlık"tan kısa süreliğine de olsa kurtulur: "Samatya Meydan'a açılan merdivenlerden inerken, apartman merdivenlerini arka arkaya silerek inen Mercan Hanııım değildi. Merdiven inerken yukarı basamakları değil aşağı basamakları görmek bile Mercan için hayatta bir basamak atlamak demekti”. Yazarın "Mercan, Mercan Hanııım' bir palto gibi çıkarı meydana inen merdivenlerin girişine asarak indi basamakları," (s.38) deyişiyle onun hem hizmet verdiği apartmanlarda oturan kadınlardan hem de yoksulluğundan böylece kurtulduğu, çok kısa bir süreliğine de olsa öykündüğü çalışan, şehirli kadına dönüşmüş olmanın sevincini duyduğu anlaşılır.

Apartmanların üst katlarında oturan kadınlarla; televizyon dizilerinden, magazin programlarından tanık olduğu lüks yaşamlarla kendini, kendi koşullarını sürekli karşılaştırır Mercan. Ancak kendi kendine söylenmekten başka isyanı olmaz; ekrandan yansıyanları uygulamaya kalktığı her seferinde yoksulluğuyla yeniden yüzleşir, ama bu yüzleşme, onu yeni denemelerden alıkoymaz.

Gül Özyeğin Başkalarının Kiri adlı kitabında, "orta ve üst orta sınıfın yaşadığı apartmanların kapıcılarının karılari" için "bodrumdaki kadınlar" ifadesini kullanır. Bu kadınlar ve gecekondu çevrelerinde oturan kadınların "orta sınıf kadınlarına iş gördükçe ve orta sınıf kadınları bodrumdaki kadınları ve gecekondu kadınlarını, kendi ücretsiz emeklerinin yerine ev işlerinde ücretli olarak çalıştırdıkça bu üç kadın topluluğunun yaşamlarının birbirini etkilemelerinin çeşitli yolları" olduğunu belirtir. ${ }^{5}$ Mercan, bir apartman görevlisinin karısı değildir; ancak ücretli olarak yaptığı iş, onu apartman görevlilerinin "gündeliğe giden” eşlerine yak-

\footnotetext{
${ }^{4}$ Seray Şahiner, Kul, İstanbul: Can Yayınları, 2017, s.9 (Yazıda verilen sayfa numaraları, kitabın bu baskısındandır).

${ }^{5}$ Gül Özyeğin, Başkalarının Kiri, çev., Suğra Öncü, İstanbul: İletişim Yayınları, 2005, s.19, 15.
} 
laştırır; apartman merdivenlerini, tırabzanları silip temizlemek, uzmanlık gerektiren bir meslek sahibi olmayan Mercan'ın geçimini sağlar; onu bu kadınlara yaklaştıran ikinci husus ise bir bodrum katında oturmasıdır. Bu noktada Gülten Akın'ın "Kapıcı Kadınlar Şiiri”" akla gelir ki şu üç dizeyle başlar şiir: "kısarak seslerini, sözlerini eksilterek / eğerek başlarını / yeraltından usulca çıkıyorlar". ${ }^{6}$ Akın, alt sınıftan olma haliyle ezik davranışlar sergilemeyi ilişkilendirir. Kısık sesle konuşmak, mümkünse hiç konuşmadan iş görmek ve baş eğmek, apartman sakinleriyle "yeraltı" nda yani bodrum katında oturan hizmetli ve ailesini birbirinden ayıran davranış biçimleri olarak değerlendirilebilir; Seray Şahiner'in Kul'da Mercan'ın görünmez oluşuyla ilgili söyledikleri de benzer bir yaklaşımın ürünüdür:

Olur da haftaya; Mercan Allah vermeye hastalansa, ah keşke arada onun yükünü alacak bir de arkadaşı olsa, Mercan'ın yerine o gelse yer silmeye, apartman sakinlerinin yeni kadına aa geçen hafta başkası vardı, sen de kimsin demeyeceği kadar fark edilmez olmalıydı Mercan. Başına bağladığı tülbenti, basma bol eteği, hatlarını belli etmeyen tişörtü ve kırmızı eldivenleri var miydı? Vardı. Tamam, apartman silen kadındı o. Mercan fark edilmeden merdivenleri silip çıkmalıydı. (134)

"İsi teknik olarak öğrenmek için annemlerin oturduğu apartmanın merdivenlerini sildim” diyen Şahiner, tıpkı Mercan gibi kapı önüne konmuş ıvır zıvırla uğraşmanın zorluğuna değinir. Apartman sakinlerinin kendisini on yıldır tanıdığı, apartmanı da on yıldır başka bir kadın sildiği halde kendisini tanımadıklarını, "kolay gelsin” demekten başka bir ilişki kurmadıklarını belirtir. ${ }^{7}$ Mercan'ın iş başındayken aklından geçenlerin aktarıldığ 1 sayfalarda, yazarın bu deneyiminin de payı vardır kuşkusuz.

Mercan, "apartman silen kadın" olarak temizlemediği bir apartmanın bodrum katında oturur. Bodrum katı daireleri küçüktür, alçak tavanlar nedeniyle basıktır; pencerelerin konumu ve küçüklüğü yüzünden yeterince ş̧ık almazlar. Mercan öğleden sonra kararan evinde lambaları erkenden yakmak zorunda kalır: "ilk taşındıklarında evin penceresi daha daha yüksekti. O zamanlar, oturduğu yerden sokakta oynayan çocukların beline kadarını görebiliyordu (...) belediye her yıl yeni asfalt ata ata pencerenin önündeki kaldırımı yükseltmiş, eve giren güneşi betonla sıvamıştı" (58-59).

Bodrum katında oturmaktan rahatsız olan Mercan, televizyon düşkünlüğünü de mekânın koşullarına bağlar: "Evi dördüncü, beşinci katta olacaktı ki televizyonu olmasa da yoldan gelip geçene pencereden bakıp oyalanacaktı Mercan. Sabahın ilk ışıklarıyla sokağı süpürmeye başlayan çöpçüleri tam boy görmek bile paraya bağglıd $\imath$ demek” (59). Mercan'ın “otuz santimlik penceresi” onu diş dünyayla buluşturacak özelliklere sahip değildir. Romanda gida alışverişinin, seçilen giysilerin; yani temel ihtiyaçların karşılanma biçiminin maddî yönleri dile getirildiği gibi, barınma ihtiyacını karşılayan ve kişinin gelir düzeyini yansıtan "ev" üzerinden de eşitsizlik vurgusu yapilır.

Mercan, oğlu olduğu hayaliyle avunduğu günlerin birinde onu herkesten ve her şeyden sakınıp bakkala bile gönderemeyeceğini düşünür: "hemen cama çıkar, bir

\footnotetext{
${ }^{6}$ Gülten Akın, Toplu Şiirler-III / Uzak Bir Kıyıda, İstanbul: Yapı Kredi Yayınları, 6. bs., 2021, s.104.

${ }^{7}$ Ayşe Arman, “Delirmesem Yazar mıyım?”, Hürriyet, 4 Mart, 2017, erişim 27 Eylül, 2021,

https://www.hurriyet.com.tr/yazarlar/ayse-arman/delirmesem-yazar-miyim-40383985.
} 
yandan sepetin dolanmış ipini çözerken aşağı 'Bakkaal!' diye seslenirdi. Bakkal kapıdan çıkınca 'iki ekmek, beş yumurta...' Hayır, bakkala sepet salamazdı Mercan, zira bodrum katta oturuyordu" (18). Bakkala sepet uzatabilmek, Mercan için onu ve onun sınıfından kadınları, üst katlarda oturan kadınlardan ayıran ve ekonomik temeli olan sembolik bir nitelik taşır. Bodrum katında oturmak, alt gelir grubuna dahil olmanın bir göstergesi, sınıfsal bir durumun ifadesidir. Oğluyla ilgili hayallerini sürdürürken okul aile birliğine girebileceğini düşünen Mercan, birliğe "sırf bakkala sepet uzatabilen kadınlar girecek diye" bir kuralın olmadığını söyler (33). İlerleyen sayfalarda karşılaştığımız "Onun nesi eksikti, üçüncü, dördüncü hatta beşinci katta oturup günlük rahat sitilleriyle bakkala sepet uzatarak hayata karışan kadınlardan?" (37) cümlesiyle, Mercan bir adım ileriye giderek ekonomik gelirin insanın toplumdaki yerini belirlemesine isyan eder görünür; bu, ondaki sınıf bilincinin filizlenmesini; bir haksızlık, bir eşitsizlik varsa bunun, kendisi dışındaki nedenlere bağlı olduğu gerçeğini fark ettiğini gösterir.

\section{Mercan’ın Yalnızlığı ve Televizyonla Kucaklaşma}

Televizyon izlemenin "ev ile doğrudan bağlantılı bir etkinlik" olduğunu belirten Tanrı̈ver'e göre "televizyon cihazının kendisi evin vazgeçilmez ve hâlâ merkezi/temel bir 'eşya'sı olduğundan, bu etkinlik gerçekten de ev içi yaşamını ve ilişkilerini belirleyici ve düzenleyici bir öneme sahiptir". ${ }^{8} \mathrm{Bu}$ özelliğiyle evlerin baş köşesine kurulan, kimi zaman oturma alanı dışındaki odalarda da kendisine yer bulan televizyon, Mercan için hayatî önem taşır; Mercan onunla yatar onunla kalkar, hazırladığı kahvaltıdan saçına sürdüğü boyaya kadar her şeyde ve neredeyse her eyleminde televizyonda gördüklerinden bir parça vardır. Sözgelimi İbrahim Tatlıses gibi görünmemek için saçını siyaha boyamak istemez; film ve dizilerdeki karakterler gibi kapıdaki paspasın altına anahtar koymak ister, sırf bu nedenle Öz Japon Pazarı'ndan bir paspas satın alır. Magazin programlarında ünlü çiftlerin el ele görüldüğü büyük alışveriş merkezlerine gidemez Mercan, televizyonun sunduklarına erişmesi kolay değildir, yaptığ karşılaştırmalar roman boyunca sürer: "Mercan televizyonda görüyordu da... İlle spor salonu ve elma yeniği atlet şart değildi. Kimisi de eşofmanını çekip Arnavutköy sahilinde elinde bir buçuk litrelik su şişesi ve yanında yaşam koçuyla yürümüyor muydu?” (20) Yaşam koçu bir yana eşofmanı bile olmayan Mercan için ulaşılabilir olan tek şey, bir buçuk litrelik sudur; bütün gün merdiven sildiğinden beş dakika ötedeki Samatya sahilinde koşacak hali de yoktur.

Televizyonun sunduğu renkli dünya, Mercan için sosyalleştiği bir gözlem alanı gibidir; o, bu dünyanın hem izleyicisi hem de bir parçasıdır. Televizyonu bozulduğunda dedesini düşünür Mercan; televizyonun aile içi sohbetleri engellediğini söyleyen dedesinin anlattığ 1 eski hikâyeleri... "Artık yoktu işte Mercan'a hikâye anlatacak kimse... Yoksa niye sevinmesindi televizyonun çalışmadiğına... Doğruldu. Acaba televizyon sürekli açık olduğundan... Şimdi bir süre dinlendiğine göre çalışır mıydı? Kalkıp lambayı yaktı. Bismillah diyerek kumandayı eline aldı" (56-57). Mercan'ın yaşadığı heyecanı okuyucuya aktarabilen yazar, onun televizyon karşısındaki gergin bekleyişini ve bu gerginliğin aslında kimsesizlikten kaynaklandığını da yansıtmayı başarır: "Allahım sen yüzüme gül. Açma tuşuna bastı. Allahım n'olur! Açılmıyordu. Mercan elinde kumanda, yerde diz çökmüş

\footnotetext{
${ }^{8}$ Hülya Uğur Tanrı̈ver, “Türkiye’de Televizyon Kültürü ve Kadınlar”, Kadın Yaşantıları, der., Ayşegül Yaraman, İstanbul: Bağlam Yayınları, 2003, s.73.
} 
çalışmayan televizyona bakıyordu. Mercan'ın televizyondan başka kimsesi yoktu" (57).

Evdeki tek başınalığını unutturan, sessizliği dağıtan televizyon, Mercan'ın can yoldaşı olmakla kalmaz; anlatıcının deyişiyle "onun yaşam koçu, stil danışmanı ve aile hekimi" olur (36). Öyle ki bir akşam televizyonun birdenbire bozulduğunu fark eden Mercan, gün geceye dönerken "havale geçiren evladını yetiştirecek acil servis arar gibi Samatya sokaklarında açık bir tamirci, bir elektrikçi bulma ümidiyle” yürür (57), tamir içinse alyansını satar (61).

Kocasını göndermişti de ne olmuştu? Adama harcadığı parayı şimdi de televizyona yediriyordu. Bunun elektriği, kumanda pili, bilmem neyi... Mercan evde olduğu sürece televizyon açıktı. Evde bir ses olmadan uyuyamazdı Mercan. Artık en yakın akrabaları, televizyon dizilerindeki oyunculardı. Yarışma programlarındaki gelin damat adaylarıyla hukuku, düğünlerinde çeyrek takmasa ayıp olacak düzeye gelmişti.

İyiydi televizyon. Gençliğinde Mercan televizyona bakıyordu. Yaşlandığında da televizyon Mercan'a bakardı. Mercan, televizyon kumandası yastığın üzerinde uyuyordu. Bir yastığa baş koymuşlardı artık, helaliydi televizyon onun. (16-17)

Kocasının gidişiyle birlikte televizyon karşısındaki çekyatta yatmaya başlayan Mercan, evlilik programlarından diyet listesi sunan doktorlara, dizilerden filmlere dek her şeyi izler; aklına yatan, heveslendiği bir şey olursa uygulamaya çalışır. Yaşadığı kimi anları Türkan Şoray'lı bir filmde yaşananlara benzettiği de olur, dizilerde gördüğ̈̈ "koca"ların "karı"larına imrendiği de. Televizyon karakterleriyle bağ kuran Mercan, gelip geçeni izleyeceği bir balkonu, penceresi olsa televizyona bu denli bağlanmayacağını düşünür; konuşup dertleşeceği bir dostu, akrabası da yoktur.

Şahiner, görmezden gelinen, yalnız bırakılan Mercan'ın tek başınalığını kentsel dönüşümle ilişkilendirir: "yıllardır yaşadığı semte, çocukken ayrıldığı mahallesini nice sonra ziyaret etmiş gibi bir şaşkınlıkla bakıyordu. (...) Şöyle bir bakıyordu da Mercan şimdi... Vay babam, buraları ne olmuştu böyle... Samatya'dan Yedikule'ye giden yol boyunca..." (78) Kısa sürede büyük bir değişim geçiren semtin eski sakinlerinden olan Fatma'nın evinin yerine yeni bir apartman dikilmiştir, Hatice'nin evinin yerinde de bir temel çukuru vardır, Elif in evi de yıkılıp gitmiştir. Mercan eski arkadaşlarından hiçbirinin kalmadığı mahallenin yeni halini yadırgar ve kendi ayrıksı duruşunun farkına varır: "Onların evlerinin yerine yükselen apartmanlara taşınanlar da ne Mercan'la oturup iki laf eder ne birlikte cemevine giderdi” (79).

Mekân-insan etkileşiminin sosyal boyutunu tek bir cümleye sığdırır Şahiner: "Fatma, eskiden evinin bulunduğu yere şimdi anca merdiven silmeye gidebilirdi" (79). Yeni yapılan konutlar, yalnızca üst gelir grubundan insanların oturabileceği niteliktedir. Mercan, semtin bu yeni yerleşimcileriyle kendi gelir grubundakiler arasındaki yaşayış farklılığını bilir; kocası çekip gitmemiş olsa onun yeni konutları nasıl anlatabileceğini de:

Valla, böyle Vatan Caddesi'nde de yok mu hani, fıskiye gibi ağaçlar. Televizyonda da çıkıyor ya, onlardan dikmişler... Yok yok, öyle anlatmazdı şöyle anlatırdı: Hani Ayşe Ablaların eski evi yok mu, gecekondu... O evin orası ne olmuş bil? Konak! Hem de, palmiyeli malmiyeli. Hani o zengin 
ağaçları yok mu, onlardan. Ayşe Abla o kadar ah ettiydi hayrını görmesinler diye, pehhh! Gelip bir yerleşmişler ki sorma... Demir parmaklıkla çevirmişler de, kapısına güvenlik görevlisi bile dikmişler. (...) Ordaki incir ağaçlarını hatırlıyor musun? Hep gitmiş. Ne diyorum sana palmiye! Sitenin duvarının dışında da bir gariban incir ağacı kalmış. Ağaca baktım baktım içim ezildi. Yok, ordan bize ekmek çıkmaz. O binalarda oturanların özel hizmetçileri vardır da böyle filmlerdeki gibi üniforma bile giyiyordur. (80$81)$.

Kul'un yukarıdaki alıntının yer aldığı sayfaları, yazarın Reklamı Atla kitabındaki bir denemesini getirir akla. Şöyle der Şahiner: "Gidenler ahlarını da bırakarak gidiyor. Ve şimdi Tarlabaşı'ndan geçenlerin muhite sinmiş ruhuyla bir ah etsek karşıki plazalar yıkılır". ${ }^{9}$ Kul'da da kentsel dönüşümün, yoğun biçimde uygulandığı Samatya'nın yapısını değiştirirken burada yaşayanların yaşamlarına olan etkisini vurgular yazar.

Şahiner, Kul'da Mercan'a, semtin yeni görünüşünü kocasının nasıl anlatabileceğini düşündürerek iki durumu birden yansıtır. İlki, bölgenin eskisine hiç benzemeyen lüks konutlarla donatılması, ikincisi ise Mercan'ın; varlığıyla kendisine bir şey katmayan kocasını arar olmasıdır. Palmiyeli sitelerden birinin duvarının dışında kalmış olan "incir ağacı"nın sembolik bir anlam taşıdığ 1 düşünülebilir; "incir ağacı", "garip"tir, dışarıda bırakılmıştır; içerideki birörnek ağaçlara uymayışı, öteki oluşu, semtin eski sakinlerinin de dışarıda kalmışlığ 1 olarak yorumlanabilir. Burada "duvar", zengin ve yoksul ayrımını belirginleştiren bir sınır olarak değerlendirilebilir. Erendiz Atasü'ye göre Kul, "hâlâ Orhan Kemal zamanına özgü kimi özellikleri örneğin hemşeri veya komşu dayanışmasını koruyan 'mahalle'nin nasıl darma duman olduğunu", "kadın birey açısından inceleyen" bir romandır. ${ }^{10}$ Romanda Mercan'ın dostsuz, arkadaşsız kalıp birkaç sözle içini dökebileceği bir ortam bulamayışında mekândaki değişim etkilidir. Evine çekilen Mercan için televizyon kurtarıcıdır; kendi gerçeğini aklından çıkarmayan Mercan, televizyonun sunduğu yaşamlarla avunur.

Sürekli bir şeyler kurar Mercan. Hayaller kurduğu gibi kendisi hakkında söylenebilecekleri de kurar kafasından. Gördüğü kadınlar, erkekler, kendisinin olmadığı için özlemle baktığı çocuklar, Mercan'ın kurmaca dünyasına dahil olurlar:

Şimdi apartmandan tek bir kişi onunla komşuluk ediyor muydu? Ama çocuğu büyüyüp de kapı önünde onların çocuklarıyla oynarken, mecbur bir hukuk kurulacaktı aralarında. Belki Haydar çok iyi top oynayacaktı da bütün çocuklar, Haydar bizi de oyuna alsın diye annelerine söyleyecek, anneleri de Mercan'dan ricacı olacaktı. Zaten Mercan, onlar gibi çocuğu sokağa salıp kapısını örtüp arkasına yaslanamazdı. Apartman kapısının önündeki merdivene bir minder atıp oturur, oğlu oynarken sokağa araba falan girerse, çocuğum kenara çekilin, derdi. Sırf kendi evladını değil, diğer çocukları da korurdu da bütün komşular minnettar kalırdı Mercan'a. (32)

Mercan'ın en büyük hayali çocuk sahibi olmaktır. Bu çocuğun erkek, ileride herkesin imrenerek baktığı "yiğit bir delikanlı" olması ise bu hayalin uç noktasıdır. Adı bile hazırdır: Haydar. Mercan, toplumsal cinsiyetinin biçtiği en önemli role

\footnotetext{
${ }^{9}$ Seray Şahiner, Reklamı Atla, İstanbul: Can Yayınları, 2016, s.84.

${ }^{10}$ Erendiz Atasü, “Şehrin Şanssızları”, Cumhuriyet Kitap Eki, sayı 1525, 9 Mayıs 2019, s.11.
} 
hayalinde bürünebilir ancak. Kocasının nerede olduğu belli değildir, çocuğu da olmamıştır. Sürekli bir bekleyiş halindedir; kocasının dönüşünü bekler, çocuğunun olacağı günü bekler. Kodlarla hareket eden bir kadın olduğundan bu ikisi olmadan kadın kimliğini yaşayamaz. Bir çocuğu olup komşu çocuklarıyla top oynaması halinde, "anne" kimliğiyle fark edilecek, bu da görünmezliğini, dikkate alınmayışını ortadan kaldıracaktır.

Mercan'ın yalnızlığı, romanın anlatımında da belirleyicidir. Kendi sorularını kendisi cevaplayan, beğenmediği cevabı bir başkasıyla değiştiren Mercan'ın bir dostu, bir sırdaşı olsa belki ona anlattıklarından ya da yazarın aktardıklarından bileceğimiz iç dünyası, yine Mercan sayesinde apaçı önümüzdedir. Şahiner, bu konuda şunu söyler: "Kul bir ayakta kalma hikâyesi... Ama beri yandan, yalnızlı̆̆ birçok yönüyle ele almaya çalıştığım bir metin. Mercan, kendi içindeki kuyulara bağırıyor yalnızlıktan, cevabı kendi yankısından alıyor". ${ }^{11}$

\section{Sokağa Çıkan Mercan'ın Bireyselliğine Yüirüyüşü}

Romanın ilk sayfalarında, aylardır kocasından ayrı olduğunu, ondan bir haber alamadığını öğrendiğimiz Mercan, kocasına "gidersen git" demenin pişmanlığını duyar. "Hiç değilse evde kavga edecek biri... Bir nefes..." (14) olacak olan bu adam, ömründe bir iş tutmamış, karısına bir güzel söz etmemiş, ot içmekten ve yan gelip yatmaktan başka bir şey yapmamış olsa da Mercan, içinde bulunduğu yalnızlığın getirdiği duygulardan "koca"sının varlığıyla kurtulabileceğini düşünür; ancak Mercan'a ağır gelen asıl yokluk, bir çocuğunun olmayışıdır. Bu iki yoksunluk durumu, romanın adının belirleyicisidir, denilebilir: "Mercan kendini adamak için yaratılmıştı. Bir kocaya, bir evlada... Bakacak kimsesi olmayınca. Mercan'ın vakit ayıracak bir kendisi de kalmıyordu” (49).

Yazarın ayrıca belirttiği gibi bir "adanmışlık hali var"dır Mercan'da; "ancak birine kul köle olursa mutlu olacak sanki... Çocuğum olsun kendimi ona adayayım, kocam olsun onunla ilgileneyim..."12 Mercan için başlangıçtaki mutluluk formülü budur. Şahiner kendisiyle yapılan bir söyleşide Mercan'ın bir erkeğe muhtaç olmaktan ziyade bir can yoldaşına ihtiyaç duyduğunu vurgular: "Yemekten sonra soyduğu meyvenin bir dilimini yanındakine uzatmayı mutluluk sayıyor. Ama bu 'hayatın ona adama' dayatmasında biraz sahtekârlık da var, kendini aldatma da... Şimdiye kadar kendisi için hiçbir şey yapmamış. Kendisiyle baş başa kalmaktan korkmakla ilgili bir durum onunki..."13 Bu yalnızlık ve kimsesizlik hali hem korkutur hem üzer Mercan'ı. Roman boyunca yalnızca bir yerde intiharı düşünür; "bileklerini kestiğinde bulup hastaneye yetiştirecek" (90) kimsesi olmadığını bildiğinden bu noktada kendisine acır da.

Çocuksuzluğu nedeniyle teselli edilmekten hoşlanmadığı için temizlik işini yeni aldığı apartmanlarda "çocuğum yok" demez Mercan; apartman sakinleri de çocuklarının küçülmüş giysilerini ona verirler; hatta öyle ki bu giysilerin çokluğu yüzünden "Mercan'ın yatak odası, ölmüş bir çocuğun anısına saygı duyularak aynen muhafaza edilen odasına" dönüşmüştür (50). Mercan izin isteyeceği

\footnotetext{
${ }^{11}$ Çavuş, “Seray Şahiner'le Söyleşi”, ss.93-94.

${ }^{12}$ Ezgi Görgü, “'Mercan Hanım’ın Yalnızlığı”, Evrensel, 11 Nisan, 2017, son güncelleme 26 Eylül, 2021, https://www.evrensel.net/haber/315412/mercan-hanimin-ayriligi.

${ }^{13}$ Arman, "Delirmesem Yazar miyım?".
} 
günlerin birinde "Bizim oğlanın, adı Haydar, Allah sizinkini bağışlasın, veli toplantısı var da..." (65) diyebilecek kadar bir yalanı sürdürmekte ileri gider. Burada, Mercan ve onun gibi işçilerin görünmezliği etkilidir. Mercan'ın yanında bir çocuk görmeyen apartman sakinlerinin temizlikçi kadın algısı şu sözlerle dile getirilir: "Ama Mercan konumunda bir kadının çocuğu, elbet olmalıyd. Hatta iki-üç tane olmalı, Mercan apartman silmeye geldiğinde büyük kız evde küçüklere bakmal,, çocuklar evde düşe kalka, yarı naçar büyümeli, yazları Mercan çocuklarını köye annesinin yanına göndermeliydi. Mercan statüsünde birine bu yakışırdı" (50).

Çocuğu olsun, tek başınalıktan kurtulsun diye adaklar adayan; camileri, türbeleri dolaşan, sık sık Kocamustafapaşa'daki Sümbül Efendi Camii'ne giderek Hz. Ali'nin torunları Çifte Sultanlar, Fatma ile Sakine'yi ziyaret eden Mercan onlardan medet umar: "Şu dünyada ölüye bile can yoldaşı lazım. Ey Çifte Sultanlar, Alinin yüzü hürmetine; Hasan'ın, Hüseyin'in başı için; ya beni de aranıza alın ya kocam geri dönsün" (11). Her inanca sarılır Mercan. Ayın Biri Kilisesi’nde mum yaktığg da olur, falcıya gittiği de. Bununla birlikte kendini en rahat hissettiği yer, cemevidir. Erikli Baba Cemevi'ne gittiğinde, "bakışı kendisininkine benzeyen bir sürü insan" bulur (85) ve yine burada, kocası gittikten sonra ilk kez yemeği tek başına yemekten kurtulur. İçselleştirdiği bir inancı vardır Mercan'ın. Cemevinde yaşadığı aidiyet duygusu ona iyi gelir; kadın-erkek, insanlar arasında bir topluluğun parçası olmanın güven veren rahatlığını duyar. Mercan, medet umduğu yerlerde başka insanların da dertlerinin olduğunu fark eder. Kendisi gibi çare arayışına girenlerin varlığını bilmek, onu rahatlatır. Bu, ondaki kıpırdanışın da nedenlerinden biri olarak yorumlanabilir.

Umutlarıyla çaresizliği arasında gidip gelen bir kadın portresi çizen Mercan'ın umutlu olmayı seçtiği gözlenir: "Kendisi apartman merdivenlerini silmeden önce kabasını alırken çalı süpürgeyi yere nasıl sürtüyorsa, umut da içinin tortusunu havalandırmak için Mercan'ı ordan oraya sürükleyen eldi” (63-64). Kocasının yolunu gözlemekten, çocuğu olma hayaliyle kıvranmaktan yorgun düşmüştür; bu yüzden de "en büyük çabayı pes etmek için" (63) gösterir Mercan. Vazgeçerse, kendini gereksiz yere meşgul eden onca şeyden kurtulacağını düşünür; ama umudu, tutunduğu daldır, onu yaşama bağlar. Yaşamını tek başına sürdürmek konusunda onu cesaretlendirebilecek düzeyde bir eğitimden geçmemiştir; nitelikli bir işi, sigortası, güvencesi yoktur; hastaneye gitmek yerine eczaneye gider, sağlık sorunlarını bu şekilde çözmeye çalışır. Düşlediği, televizyonda gördüğü cinsten bir yaşantıya kavuşmasını sağlayacak her şeyden; İstanbul'un orta yerinde yaşasa da onun güzelliklerinden uzaktır. Yaşamının tüm bu olumsuz yanlarına karşın bir köşeye çekilip kollarını kavuşturmaması, mücadelesini sürdürmesi, Mercan'ın en güçlü yönüdür. Samatya Meydan'a açılan merdivenlerden inerken hissettikleri, apartman temizleyicisi "hanııı" olmaktan, dolayısıyla görünmezlikten kurtulmasıyla ilişkilidir. O dakikalarda yalnızca "Mercan"dır ve bu ad, kendisine zaman ayırmaya başlayan bir kadının adıdır Mercan için. "Ne vardı yani kendisini evlere kapatıp kocası gitti diye televizyonun metresi olacak? İnsan içine çıkmak gibisi var mıydı?” (42) Böyle düşündüğü gün Samatya Meydanı’na geçip kendisine bir bira 1smarlar; çekingen, tedirgin davranışlar içinde, oturduğu masada telefonla konuşuyormuş gibi yapar; elini, parmağındaki yüzüğü gösterecek şekilde hareket ettirerek, "evli" olmanın verdiği güven duygusunu arar. Böyle davranmakla birlikte Mercan gibi tek başınalığından muzdarip bir kadının tek başına bir yerde oturup bira içmesini bir adım olarak değerlendirebiliriz; istediği bir şeyi tek başına da olsa 
yapabileceğini kendine kanıtlama yolunda bir adım.

Mercan'ın kendine yetebilmesi konusunda en büyük desteği, işidir. Severek yapmasa da işinin kıymetini bilir Mercan; çünkü işi, İstanbul gibi büyük ve yoğun nüfuslu bir kentte kendi ayakları üzerinde durabilmesini, temel ihtiyaçlarını karşılayabilmesini sağlar. Evine gıda olarak aldıkları "ancak bir barbi evinin buzdolabı"nı doldurmaya yetse de kendi kazandığını harcamanın erincini duyar: "Çok şükür çalışmıştı da, böyle alışveriş yapabiliyor, market poşetlerinden malzemeyi çıkarıp tek tek dolaba koyuyordu" (53).

Seray Şahiner Kul'da bilinçli bir kadını değil; farklı kesimlerin koşullarını gözleyen, karşılaştırmalar yapan, gördüklerini sorgulamaya başlayan bir kadını anlatır. Mercan, alıştığı koşullarda yaşamını sürdüren birçokları gibi "böyle gelmiş böyle gider" demez; sorgular. Bu, bir anlamda bir uyanışın, kadınlığın toplumsal anlamını sorgulamaya başlamasının ilk adımları, ilk kıvılcımları sayılabilir. Bütün romana yayılan "Neyi/neyim eksik?"li ifadeler, çekememezlik ve kıskançlık duygusuyla açıklanamaz. Yanında kocası/sevgilisi ya da çocuğu olan kadınlara gıpta ile bakan Mercan'ın her ikisine de sahip olmayışıyla ilgili soruları, başka soruları da beraberinde getirir.

\section{Orhan Kemal Roman Armağanı}

Orhan Kemal yazarlığının neredeyse temel özelliği halkı anlatmasıdır. Orhan Kemal'in öykülerinde ve romanlarında hep halktan insanlarla karşılaşırız; işçiler, köyünden kopmuş ama daha işçileşememiş emekçiler, kenar mahallelerde yaşayanlar, yoksul kadınlar, bir biçimde emeğini satarak yaşamını sürdürenler... Bir yazar, kalemini, gözünü toplumsal gerçeklere yöneltmişse; halkı, kenarda kalmış kadınları, erkekleri anlatmaya başlamışsa, bir anlamda -değişen toplumsal koşulları unutmamak kaydıyla- Orhan Kemal'in insanlarının günümüzdeki uzantılarını, onun çocuk ve kadınlarını, erkeklerini anlatıyor gibi bir hava yaratabilir. Seray Şahiner'in Mercan'ı da Orhan Kemal'in romanlarının birinden çıkıp gelmiş gibidir. Eray Ak'ın deyişiyle "bugünün dertleriyle yoğrulmuş farklı bir Orhan Kemal kahramanından başkası değildir”. ${ }^{14}$ Ak'ın; Mercan'ın mücadelesi hakkında söyledikleri, Kul'un 47. Orhan Kemal Roman Armağanı'nı alacak oluşunun habercisi gibidir:

Göz önünde olup da görünmeyenlerin görüldüğü, sesleri çıssa da duyulmayanların işitildiği bir dünyaydı Orhan Kemal'in yazdıklarında edebiyatımıza kazandırdığı. Seray Şahiner de Kul'da var olsa da olmayan, yok olacaksa bile çaresizliğinden olamayan bu insanların dünyasına yeni bir çerçeve kazandırıyor. Bir kadının çerçevesi bu. Öğretilmiş hayallerinden başka dünyası olmayan ama bunlar için de yine öğretilenlerin dışına çıkamadan mücadelesini sürdüren bir kadın... ${ }^{15}$

İlkin 1972'de verilen Orhan Kemal Roman Armağanı'nı bugüne dek -1981'deki verilmeyişi dışında- kırk dokuz isim kazanmıştır; bu yazarlardan sekizi, kadındır: 1974 - Sevgi Soysal, Yenişehir'de Bir Öğle Vakti; 1980 - Adalet Ağaoğlu, Bir Düğ̈̈̈n Gecesi; 1991 - Peride Celal, Kurtlar; 1996 - Erendiz Atasü, Dağın Öteki Yüzü; 2001

\footnotetext{
${ }^{14}$ Ak, "Sadaka Niyetine Mutluluk", s.8.

${ }^{15}$ Ak, "Sadaka Niyetine Mutluluk", s.8.
} 
- Oya Baydar, Sıcak Külleri Kald $; 2004$ - İnci Aral, Mor; 2008 - Ayşegül Devecioğlu, Ağlayan Dă̆ Susan Nehir; 2018 - Seray Şahiner, Kul. Kula verilen armağanın gerekçesi şöyle ifade edilir:

Seray Şahiner'in 'Kul' romanı kentsel ve rantsal dönüşümle mahallenin çöküşü, kadın bireyin tamamen yalnızlaşmasını, tek başına bir birey olarak var olma mücadelesini, hezeyan, beklenti ve umutlarını, düş kırıklıklarını, topluma hâkim olan çeşitli söylemlerden, ideoloji ve inançlardan nasıl etkilendiğini, bu etkileri kişiselleştirip aradan kendi yolunu bulmaya çalışışıını, bu etkilerden kurtulamayışını ama gene de teslim olmayışını güçlü bir anlatım tekniğiyle ve tutarlı bir dille, kolaycılıklara sapmadan ince bir mizahla toplumsal dokuyu arka planda ustalıkla irdelemesi ve Orhan Kemal'in sanat ve dünya görüşüyle birebir örtüşmesi nedeniyle 47. Orhan Kemal Roman Armağanı'na değer görülmüştür. ${ }^{16}$

Seçici kurulun Kul'a armağan verme gerekçesi, hem romanın taşıdığı anlamı kapsamlı bir biçimde belirtmesi hem de sözü edilen özelliklerin Orhan Kemal romancılığının da özellikleri olduğunu vurgulaması açısından önemlidir. Gerçekten de Kul, Orhan Kemal'in yazı dünyasından kendisine konuk gelen Mercan karakteriyle, onun dünyasını yaşatma görevini yerine getiriyor gibidir.

\section{Sonuç}

Son dönemde Türk edebiyatında kadın yazarların, özellikle öykü ve roman yazımında geçmişe göre, çok daha yoğun bir üretim sürecine girdiklerini gözlüyoruz. Günümüz yazarlarından Seray Şahiner de 2007'de yayımlanan ve öykülerden oluşan Gelin Başı'ndan bu yana çalışmalarını aralıksız sürdüren ve yazdıklarıyla ses getiren bir yazar olarak dikkati çekmektedir. Bu çalışmanın odağındaki Kul, yazarın ikinci romanıdır ve Orhan Kemal Roman Armağanı'nı kazanmıştır. Yalnızlık ve çaresizlik duygularıyla umutları arasında sıkışıp kalmasına rağmen çıkış yolları arayan Mercan'ın İstanbul'daki yaşamına odaklanan Kul, onun tek başına sürdürdüğü yaşamındaki eksiklikleri, televizyonla kurduğu ilişkiyi, çekip gitmiş kocasıyla doğmamış çocuğuna duyduğu özlemi ve her şeye rağmen pes etmeyişini anlatan bir romandır.

Şahiner kahramanını, çok iyi bildiği bir çevre olan Samatya'dan seçmiş; Mercan'ın yalnızlığını, bölgeye hâkim olan kentsel dönüşümle ilişkilendirmiştir; çünkü Mercan, sadece evi terk eden kocasından değil başka yerlere taşınmak zorunda kalan arkadaşlarından da ayrı düşmüştür. Televizyonla ve televizyon karakterleriyle bağ kurmasının bir nedeni de budur. Tek bir karakter üzerinden ilerleyen romanda, Mercan'ın yaşadıklarıyla birlikte aklından geçenleri de okuyucuya ileten yazar, iç konuşma tekniğine başvurarak Mercan'ın iç dünyasını gözler önüne sermiştir. Şahiner, eğitimi ve nitelikli bir işi olmayan, sosyal güvenceden yoksun karakterinin yalnızlığını, kenarda kalmışlı̆ını anlatırken onun; evli, çocuklu ve görünür olma arzusunu; kendini adayacağı birine ihtiyaç duyma halinden küçük adımlarla da olsa kendine yetebilme haline geçişini yansıtmıştır. Mercan, fark edilmeden yaşadığının farkında olan bir kadındır; sevilmek, önemsenmek ister; evli olsa da kocası yanında değildir, evli gibi görünmez; anne de olamamıștır. Toplumun kadında görmek istediği iki nitelikten de yoksun olma durumu, kendisi de bu anlayışla yetiştirilmiş Mercan'da eksiklik duygusu uyandırır; bu da var olan yalnızlık

${ }^{16}$ Orhun Atmış, "Beni Edebiyatçllar Örgütledi”, Cumhuriyet, 2 Haziran, 2018, s.13. 
duygusunu pekiştirir. Onun, çevresinde ve televizyonda gördükleriyle kendi koşullarını karşılaştırması, sorgulamaya başlamasını da beraberinde getirir.

Ülkede ve dünyada olup bitenleri izlemek zorunluluğu duyan bir yazar elbette toplumsal mücadelelerin ön saflarında yer alan kadınları anlatmak, gerçeğin dürüst bir gözlemcisi olarak hayal ettiği kadınları değil, bugün olmasa da yarın bu mücadelede yer alacak kadınları yazmak isteyecektir. Seray Şahiner'in Mercan'1, Kul'un bittiği yerde değil, belki çok yakın bir gelecekte de değil, ama zaman içinde kadınlığın toplumsal anlamı üzerinde düşünecektir; duyargaları açık bir kadın olduğundan kadın mücadelesinin farkına varacak ve bunda yerini alacaktır.

\section{Kaynakça}

Ak, Eray. "Sadaka Niyetine Mutluluk". Cumhuriyet Kitap Eki. 1412 (2017).

Akın, Gülten. Toplu Şiirler-III/Uzak Bir Kıyıda. İstanbul: Yapı Kredi Yayınları, 6. bs., 2021.

Arman, Ayşe. “DelirmesemYazar mıyım?”. Hürriyet. 4 Mart, 2017. Erişim 27 Eylül, 2021. https://www.hurriyet.com.tr/yazarlar/ayse-arman/delirmesem-yazarmiyim-40383985.

Atasü, Erendiz. “Şehrin Şanssızları”. Cumhuriyet Kitap Eki. 1525 (2019).

Atmış, Orhun. "Beni Edebiyatçllar Örgütledi”. Cumhuriyet. 2 Haziran, 2018.

Cansever, Edip. Sonrası Kalır I. İstanbul: Yapı Kredi Yayınları, 10. bs., 2013.

Çavuş, Beyza Selen. “Seray Şahiner’le Söyleşi”. Varlık. 1318 (2017).

Görgü, Ezgi. “'Mercan Hanım’n Ayrılı̆̆ı”. Evrensel. 11 Nisan, 2017. Erişim 26 Eylül, 2021. https://www.evrensel.net/haber/315412/mercan-haniminayriligi.

Özyeğin, Gül. Başkalarının Kiri. Çev., Suğra Öncü. İstanbul: İletişim Yayınları, 2005.

Şahiner, Seray. Kul. İstanbul: Can Yayınları, 2017.

Şahiner, Seray. Reklamı Atla. İstanbul: Can Yayınları, 2016.

Uğur Tanrı̈ver, Hülya. “Türkiye'de Televizyon Kültürü ve Kadınlar”. Kadın Yaşantıları. Der., Ayşegül Yaraman. İstanbul: Bağlam Yayınları, 2003: 51-74. 